\title{
Uji Mikroorganisme pada Cabai (Capsicum annuum) Bakso yang Disajikan di Tempat Penjualan Bakso di Kecamatan Padang Timur
}

Raja Nona Millani ${ }^{1}$, Netti Suharti ${ }^{2}$, Asterina $^{3}$

\begin{abstract}
Abstrak
Bakso merupakan salah satu kuliner yang favorit bagi sebagian besar kalangan. Penikmat bakso selalu mencampurkan cabai sebagai penambah rasa pedas. Pada beberapa tempat penjualan bakso banyak kemungkinan terjadinya kontaminasi pada cabai yang disajikan diantaranya tempat cabai bakso yang kurang bersih. Tujuan penelitian ini adalah memeriksa mikroorganisme pada cabai bakso yang disajikan di tempat penjualan bakso di Kecamatan Padang Timur. Penelitian deskriptif ini dilakukan di Laboratorium Mikrobiologi Fakultas Kedokteran Universitas Andalas dari Oktober 2013 sampai Desember 2014. Jumlah sampel adalah 20 yang diambil dari tempat penjualan bakso di Kecamatan Padang Timur. Hasil penelitian menunjukkan sebagian besar sampel (90\%) mengandung bakteri yaitu Klebsiella sp, Enterobacter sp, Proteus sp, Bacillus sp,Streptococcus sp dan sisanya $10 \%$ mengandung candida. Diharapkan konsumen berhati-hati dalam mengkonsumsi cabai bakso yan disajikan ditempat penjualan bakso.
\end{abstract}

Kata kunci: cabai, bakso, bakteri

\begin{abstract}
Meatball is a favorite culinary food among citizens. People use spicy chili as a dipping sauce to enhance flavour. In most of the meatballs selling stalls, there are high possibilites of the chili served getting contaminated for example, due to the lack of cleanliness of the chili serving containers. The objective of this study was to identity the presence of the microorganisms in dipping sauce served in meatballs selling stalls in Padang Timur District. This research was conducted in the Laboratory of Microbiology, Faculty of Medicine, University of Andalas from October 2013 to December 2014 using descriptive method. A total of 20 samples were taken from the meatball stalls in Padang Timur District. Based on the results, The result showed that $90 \%$ of the samples contain bacteria such as Klebsiella sp, Enterobacter sp, Proteus sp, Bacillus sp, Streptococcus $s p$ and the remaining $10 \%$ contain candida. Therefore, consumers are advised to be more cautious in consuming foods from meatball stalls.
\end{abstract}

Keywords : chili, meatball, bacteria

Affiliasi penulis: 1. Prodi Profesi Dokter FK UNAND ( Fakultas Kedokteran Universitas Andalas Padang), 2.Bagian Mikrobiologi FK UNAND, 3. Bagian Kimia FK UNAND

KorespondensI: Raja Nona Millani, Email:

millanirajanona@gmail.com, Telp: 085271555150

\section{PENDAHULUAN}

Cabai (Capsicum annuum) merupakan tumbuhan buah atau sayuran. Tanaman ini sangat mudah ditanam. Cabai bentuknya bermacam-macam dan warnanya bervariasi. Dalam kehidupan sehari-hari cabai merupakan kebutuhan pokok manusia yang dapat diolah menjadi bumbu penyedap masakan yang di gunakan sebagai rempah-rempah (bumbu dapur). Cabai mengandung vitamin $\mathrm{A}$, vitamin $\mathrm{C}$, vitamin $\mathrm{K}$ dan lain-lain yang dibutuhkan oleh tubuh, serta mengandung minyak atsiri capsaicin yang menyebabkan rasa pedas bila digunakan untuk rempah-rempah. ${ }^{1}$ 
Berdasarkan observasi pendahuluan, pada beberapa tempat penjualan bakso banyak kemungkinan terjadinya kontaminasi pada cabai bakso yang disajikan; seperti tempat cabai bakso yang kurang bersih, cabai yang disajikan sudah berubah warna dan berbau tidak sedap yang kemungkinan produsen tidak mengganti cabai yang disajikan setiap harinya dan menyimpan cabai di waktu yang lama dengan cara yang salah ataupun produsen mencampur cabai lama dengan cabai yang baru. Kontaminasi yang memungkinkan dari konsumen yaitu konsumen kurang memperhatikan higiene dengan menggunakan sendok yang sudah digunakan untuk mengambil cabai yang disajikan serta menambahkan cabai disaat kuah bakso tidak dalam keadaan panas lagi sehingga apabila ada kontaminasi terhadap bakteri patogen pada cabai dapat memungkinkan konsumen terkena penyakit atau gangguan kesehatan. Hal ini menyebabkan sangat rentan terjadinya kontaminasi bakteri terhadap cabai bakso.

Banyaknya kemungkinan kontaminasi pada cabai bakso sangat memungkinkan adanya bakteri patogen yang dapat menimbulkan penyakit atau gangguan kesehatan. Bakteri Escherichia coli adalah salah satu bakteri indikator untuk menilai sanitasi makanan. Menurut Keputusan Menteri Kesehatan Republik Indonesia Nomor 1098/Menkes/SK/VII/2003 tentang Persyaratan Higiene Sanitasi Rumah Makan dan Restoran, angka kuman Escherichia coli dalam makanan disyaratkan 0 per gram makanan. Bakteri patogen

Makanan yang terkontaminasi oleh
Staphylococcus aureus yang memproduksi
enterotoksin mengakibatkan muntah dan diare akut
dalam 4 hingga 6 jam sesudah tertelan yang biasanya
terkontaminasi lewat penjual/pengolah makanan. ${ }^{2}$
Di Kota Padang terutama Padang Timur,
banyak terdapat kuliner bakso dan di daerah ini sebagian besarnya ditempati oleh mahasiswa maupun pelajar yang menjadikan tempat bersantai sambil menikmati hidangan bakso.

\section{METODE}

Jenis penelitian yang dilakukan adalah deskriptif untuk mengetahui mikroorganisme pada cabai bakso yang disajikan ditempat penjualan bakso di Padang Timur.

Penelitian telah dilakukan di Laboratorium Mikrobiologi Fakultas Kedokteran Universitas Andalas Padang dengan mengambil sampel cabai bakso yang disajikan ditempat penjualan bakso di Padang Timur. Waktu pelaksanaan penelitian adalah dari Oktober 2013 sampai Desember 2014 mulai dari pengumpulan bahan tulisan penelitian sampai laporan akhir skripsi.

Populasi dalam penelitian ini adalah accessible population meliputi 20 tempat penjualan bakso yang menyajikan cabai ditempat penjualan bakso di Padang Timur. Accessible population atau populasi terjangkau adalah populasi yang dapat dijangkau oleh peneliti serta dibatasi oleh tempat dan waktu. Jadi jumlah sampel minimal yang didapatkan adalah 17 cabai bakso.

Sampel penelitian diambil secara acak dengan metode simple random sampling sehingga setiap anggota populasi memiliki kesempatan yang sama untuk dipilih sebagai sampel dan dengan drop out $20 \%$ sehingga pada penelitian ini diambil total sampel yaitu 20 cabai bakso.

\section{HASIL}

Hasil penelitian terhadap 20 sampel cabai bakso yang disajikan di beberapa tempat penjualan bakso di Kecamatan Padang Timur didapatkan semua sampel mengandung mikroorganisme sesuai tabel berikut :

Tabel 1. Kontaminasi kuman pada cabai bakso

\begin{tabular}{ll}
\hline Mikrooranisme & Jumlah Sampel \\
\hline Bakteri & 18 sampel \\
Jamur & 2 sampel \\
Total & 20 sampel \\
\hline
\end{tabular}


Pada Tabel 1 dapat dilihat sebagian besar sampel mengandung bakteri dengan persentase $90 \%$ dari seluruh sampel dan sampel mengandung jamur dengan persentase $10 \%$.

Tabel 2. Distribusi frekuensi jenis bakteri pada sampel cabai bakso

\begin{tabular}{lcc}
\hline Jenis Kuman & Frekuensi & $\%$ \\
\hline Klebsiella $s p$ & 5 & $25 \%$ \\
Enterobacter $s p$ & 3 & $15 \%$ \\
Proteus $s p$ & 3 & $15 \%$ \\
Bacillus sp & 5 & $25 \%$ \\
Streptococcus sp & 2 & $10 \%$ \\
Candida & 2 & $10 \%$ \\
Jumlah kuman & 20 & $100 \%$ \\
\hline
\end{tabular}

Pada Tabel 2 dapat dilihat kuman Klebsiella dan Bacillus terbanyak ditemukan, yaitu 25\% dari seluruh sampel penelitian. Streptococcus dan Candida yang sedikit ditemukan, yaitu $10 \%$ dari seluruh sampel penelitian.

\section{PEMBAHASAN}

Hasil penelitian menunjukkan semua sampel cabai bakso mengandung kuman. Ada 18 sampel terkontaminasi bakteri dan dua sampel terkontaminasi kandida. Kontaminasi kuman juga ada yang ditemukan pada makanan jajanan bakso tusuk di Manado dengan kandungan Escherichia coli $85 \%$ dan Salmonella $s p$ $45 \%$ sampel. $^{3}$ Ketentuan kontaminasi kuman patogen adalah 0 per gram makanan. Kuman yang ditemukan bersifat patogen untuk manusia sehingga dapat menyebabkan infeksi dengan perantara makanan dan minuman yang dikonsumsi konsumen. Resiko infeksi dipengaruhi oleh sistem kekebalan tubuh individu, virulen patogen usus dan jumlah kuman yang masuk kedalam saluran pencernaan. ${ }^{4}$

Sumber kontaminasi kuman patogen pada cabai bakso kemungkinan dapat berasal dari cabai itu sendiri, produsen yang mengolah cabai bakso, alatalat yang digunakan dalam pengolahan tidak higienis, penyimpanan cabai bakso, tidak mengganti cabai bakso setiap harinya, penyajian cabai bakso dan menggunakan sendok yang sudah digunakan untuk pengambilan cabai. Kontaminasi cabai bakso yang terjadi kemungkinan disebabkan oleh pengetahuan produsen tentang sanitasi dan higiene sangat kurang, mulai dari proses pengolahan yang tidak memenuhi syarat standar yang sudah ditentukan sampai proses penyajian makanan. Tempat pengolahan yang tidak memenuhi syarat standar sanitasi dan higienis memungkinkan serangga hinggap pada cabai yang membawa kuman patogen. Kondisi udara yang tidak bersih seperti debu juga dapat menambah kontaminasi pada cabai bakso.

Kelompok mikroorganisme tersebar luas di alam yang dapat menyebabkan penyakit pada manusia. Pada dewasa normal, esofagus mengandung mikroorganisme yang masuk bersama saliva dan makanan. Keasaman lambung menjaga jumlah mikroorganisme pada angka $10^{3-1} 10^{5} / \mathrm{g}$ kandungan. $\mathrm{pH}$ asam yang normal pada lambung melindungi dari infeksi oleh beberapa patogen enterik. Kuman enterik dapat menyebabkan diare, muntah, sakit perut dan demam. Kuman gram positif menyebabkan keracunan pada makanan yang dapat menyebabkan diare. ${ }^{4}$

Hasil identifikasi yang dilakukan pada sampel cabai bakso diperoleh 6 jenis kuman, yaitu Klebsiella sp, Enterobacter sp, Proteus sp, Bacillus sp, Streptoccocus $s p$ dan candida. Kuman Klebsiella $s p$, Enterobacter $s p$ dan Proteus $s p$ termasuk golongan koliform yang tergolong kuman intestinal yaitu hidup di dalam saluran cerna manusia. Kuman koliform merupakan indikator adanya kontaminasi kotoran dan kondisi sanitasi yang kurang baik pada makanan, air dan susu. Kuman Bacillus sp dan Streptoccocus $s p$ adalah kelompok bakteri gram positif yang dapat menimbulkan penyakit, sedangkan fungi (spesiescandida) ditemukan di mulut sebagai flora normal yang kadang-kadang dapat menimbulkan penyakit. $^{4}$

Berdasarkan distribusi frekuensi kuman enterik lebih banyak ditemukan daripada kelompok kuman gram positif maupun kandida karena kuman enterik gampang hidup dalam suasana lembab. ${ }^{5}$ 


\section{KESIMPULAN}

Terdapat kuman pada semua sampel cabai bakso yang dijual di Kecamatan Padang Timur Kota Padang.

Sebagian besar sampel $(90 \%)$ mengandung bakteri yaitu Klebsiella $s p$, Enterobacter $s p$, Proteus $s p$, Bacillus sp,Streptococcus sp dan ditemukan 10\% sampel mengandung candida.

\section{UCAPAN TERIMAKASIH}

Terimakasih kepada semua pihak atas bimbingan dan bantuannya sehingga penelitian ini dapat selesai.

\section{DAFTAR PUSTAKA}

1. Suriana N. Cabai sehat dan berkhasiat. Yogyakarta: CV ANDI OFFSET; 2012.

2. Sears Benjamin W, Spears L, Saenz R. Intisari mikrobiologi \& imunologi (terjemahan). Jakarta: EGC; 2011.

3. Arlita Y. Identifikasi bakteri Escherichia coli dan Salmonella sp pada makanan jajanan bakso tusuk di Kota Manado (skripsi); 2014.

4. Brooks Geo F, Karen C. Carroll, Janet S Butel, Stephen A Morse, Timothy A Mietaner. Jawetz, Melnick, \& Adelenberg's medical microbiology (terjemahan). Jakarta: EGC; 2013.

5. Universitas Indonesia. Buku ajar mikrobiologi kedokteran (edisi revisi). Tangerang: Binarupa Aksara;2010. 